\title{
An updated view on the differentiation of stem cells into endothelial cells
}

\author{
ZHOU YiJiang, YANG Feng, CHEN Ting, WU YuTao, YANG Mei, ZHU JianHua \\ \& ZHANG $\mathrm{Li}^{*}$
}

Department of Cardiology, the First Affiliated Hospital of Zhejiang University, School of Medicine, Hangzhou 310003, China

Received May 14, 2014; accepted June 16, 2014

\begin{abstract}
Endothelial cells form the internal barrier between circulating blood and the vessel wall. They regulate arterial activity and mediate pathological reactions to vascular injuries such as atherosclerosis and balloon angioplasty. The development and differentiation of endothelial cells is a complex and coordinated process involving multiple levels of signaling and transcriptional and post-transcriptional regulation. Elucidating the mechanism of endothelial differentiation will not only enhance our understanding of vascular disease pathogenesis, but also facilitate our ability to produce vessels cells from pluripotent stem cells for regeneration purposes. In this review, we discuss the current understanding of how stem cells differentiate into endothelial cells at the level of signaling, transcription and microRNA regulation.
\end{abstract}

stem cells, endothelial cells, differentiation, signaling, transcription, microRNA

Citation: Zhou YJ, Yang F, Chen T, Wu YT, Yang M, Zhu JH, Zhang L. An updated view on the differentiation of stem cells into endothelial cells. Sci China Life Sci, 2014, 57: 763-773, doi: 10.1007/s11427-014-4712-4

The vascular system is fundamental for embryonic development and adult life because it is essential for the delivery of oxygen and nutrients to cells throughout the body. Endothelial cells (ECs) line the internal surface of the entire vascular system and form the barrier between circulating blood and the rest of the vessel wall. They serve to prevent thrombosis and to regulate arterial activity through synthesis and release of numerous vasoactive molecules. The endothelium is thus considered as a dynamic and heterogeneous organ with secretory, metabolic, synthetic and immunological functions [1]. In mammals, two distinct but related processes are involved in the establishment of blood vessels [2]: First, de novo vasculogenesis generates a primitive network of vasculature through the formation of ECs from endothelial precursor cells called angioblasts. Second, angiogenesis takes place with vessel expansion and further

*Corresponding author (email: li.zhang.uk@gmail.com)
EC sprouting, branching and intussusception. Further specialization of the endothelial cells into arteries, veins, capillaries and lymphatic vessels ensures the proper functioning of the vasculature.

Differentiation of endothelial cells from their precursors involves co-operative interaction among many different signaling molecules and transcription factors (for reviews, see $[3,4]$ ). Understanding the molecular mechanism of EC differentiation will greatly benefit regenerative methods for treating certain vascular diseases, such as atherosclerosis, aortic dissections and aneurysms. Various methods have been applied to generate endothelial cells from pluripotent stem cells, which include embryonic stem cells (ESCs) and induced pluripotent stem cells (iPSCs), but often with limited efficiency. Thus, new techniques and refined protocols are needed to produce sufficient numbers of a desired cell type for tissue engineering and regenerative medicine. Over recent years, there has been great progress in our under- 
standing of how molecules participate in endothelial lineage commitment. In this review, we discuss the signaling pathways and transcriptional regulation of endothelial differentiation and also the involvement of microRNAs during this process.

\section{Signaling pathways involved in the regulation of endothelial differentiation}

Establishment of endothelial cells occurs both extraembryonically and intraembryonically during mammalian embryonic development. In the yolk sac, mesodermal precursors of hematopoietic and endothelial lineages differentiate into a cluster of cells called blood islands, where cells in the inner part of the island give rise to hematopoietic cells and cells in the outer part differentiate into endothelial cells [3]. The subsequent coalescence of blood islands and the formation of the lumina lead to a primitive vascular plexus. Within the embryo, endothelial precursor cells called angioblasts migrate and differentiate to form the primordial aorta. Simultaneous migration of angioblasts from presomitic cranial mesoderm forms the endocardial tube in the pericardial area [4].

Several signaling pathways, including those for hedgehog $(\mathrm{Hh})$, vascular endothelial growth factor (VEGF), basic fibroblast growth factor (bFGF), bone morphogenetic protein (BMP), Notch and Wnt, are required for induction of endothelial and hematopoietic lineages within the endoderm [5]. Although the current model of signaling hierarchy controlling endothelial cell development is largely derived from studies of mouse, endothelial differentiation in different mammalian species seems to adopt a similar signaling program $[6,7]$.

\subsection{Hedgehog signaling}

Signaling by the Hedgehog family of secreted proteins plays a key role in embryonic patterning and morphogenesis [8] and is essential for vertebrate blood vessel formation [9]. The Hedgehog family consists of three members: sonic hedgehog $(\mathrm{SHH})$, Indian hedgehog $(\mathrm{IHH})$ and desert hedgehog (DHH). IHH, a primitive endoderm-secreted protein, is sufficient to induce formation of endothelial and hematopoietic cells in the mouse embryo with the endoderm removed [10]. SHH, a more widely expressed protein during embryogenesis and which shares a redundant role with IHH [11], was also shown to be both necessary and sufficient for endothelial tube formation from angioblasts in avian embryos [12]. Zebrafish embryos mutant in the $\mathrm{SHH}$ pathway display a defect in vascularization and a loss of arterial differentiation, and overexpression of SHH leads to the formation of lumenized ectopic vessels [13]. Embryoid bodies formed from mouse embryonic stem cells deficient in either Ihh or a receptor component of the Hh pathway,
Smoothened (Smo), are unable to form blood islands and express no endothelial cell markers [14]. However, $I h h^{-/-}$ embryo yolk sacs can form blood vessels, although the vessels are fewer in number and are smaller [14], indicating that Hh signaling may play an inductive role in directing mesoderm differentiation but not a direct role in endothelial cell differentiation.

\subsection{Bone morphogenetic protein signaling}

Bone morphogenetic proteins function downstream of Hedgehog signaling [6,7] and are also critical for regulating embryonic vascular development. First identified in extracts from bone matrix and with a role of promoting bone formation, BMPs are now known as essential regulators of the development of nearly all vertebrate organs systems, including the embryonic vasculature. Bmp4 knockout mice are embryonic lethal due to failed generation of mesoderm [15]. Embryos deficient for downstream BMP signaling molecule Smad5 lack organized yolk sac vasculature [16]. BMP4 initiates efficient induction of mesoderm in human embryonic stem cells $[17,18]$ and can promote formation of Flk $-1^{+} \mathrm{Scl}^{+}$hematopoietic and endothelial progenitors [19], $\mathrm{CD} 34^{+}$progenitors [20], $\mathrm{CD} 34^{+} \mathrm{CD} 31^{+}$vascular progenitors [21], $\mathrm{CD} 44^{+} \mathrm{KDR}^{+}$endothelial progenitors [22] and hemogenic endothelium from murine ESCs [23].

The VEGF receptor, Flk-1, is now recognized as a target of BMP signaling. BMP4, via SMAD1/5 signaling, induces differentiation of ESCs into Flk- $1^{+}$cells in serum-free conditions [19]. Recent studies have identified several transcription factors that mediate BMP4-induced EC differentiation. CXXC5, a nuclear transcription factor containing a CXXC-type zinc-finger domain, is induced during endothelial differentiation from mouse ESCs and mediates transcriptional activation of $F l k-1$ via BMP4-Smad signaling [24]. Cxxc5 morpholino-injected zebrafish display defects in caudal vein plexus formation, and $\mathrm{Cxxc5}^{-/-}$mice with subcutaneously injected matrigel plugs show suppressed BMP4-induced angiogenesis, suggesting that Cxxc5 is required for vessel formation. ER71/ETV2, a member of the ETS (E26 transformation-specific or E-twenty-six) transcription factor family, promotes BMP4-mediated Flk- $1^{+}$ cell development and overexpression can rescue the formation of Flk- $1^{+}$mesoderm blocked by BMP [25]. Another study showed that Gata2, one of the blast colony-forming cell (BL-CFC)-enriched transcripts, was a direct target of BMP4 and was able to promote generation of Flk- $1^{+}$mesoderm and Flk- ${ }^{+} \mathrm{Scl}^{+}$hemangioblasts [26].

\subsection{WNT signaling}

The WNT family of proteins are secreted glycoproteins that control fundamental aspects of development, including embryonic patterning, cell fate specification, survival, and overall organogenesis [27]. There are three main WNT sig- 
naling pathways: the canonical WNT/ $\beta$-catenin pathway, the WNT/ $\mathrm{Ca}^{2+}$ pathway, and the planar cell polarity (PCP) pathway. Canonical WNT signaling is the most extensively studied and plays a critical role in vascular development. Deletion of $\beta$-catenin in developing endothelial cells leads to embryonic death and loss of EC integrity [28]. The canonical WNT pathway is required for primitive streak formation $[29,30]$ and initial formation of mesoderm from the pluripotent epiblast or mouse ESCs. Further differentiation of ESCs into hematoendothelial cells still requires canonical WNT signaling [31]. Inhibition of WNT leads to decreased generation of Flk-1 $1^{+}$cells [32], whereas activation of the WNT signal is able to expand Flk-1 ${ }^{+}$vascular progenitor populations [33]. A definite role of WNT signaling in directing differentiation of embryonic stem cells into the endothelial lineage has been identified with Wnt5a deficient murine ESCs [34]. Wnt5a $a^{-/}$mouse ESCs exhibited a defect in endothelial differentiation, which could be rescued by adding recombinant WNT5a protein. In addition, both the canonical $\beta$-catenin and the PKC $\alpha$-mediated non-canonical signaling pathways are required for the differentiation of mESCs to ECs induced by Wnt5a [34].

\subsection{VEGF signaling}

VEGF signaling is the key regulatory pathway controlling vascular development and diverse endothelial cell functions, including cell survival, proliferation, migration and vascular permeability [35]. Among the five members of the VEGF family, which includes VEGFA, VEGFB, VEGFC, VEGFD and VEGFE, VEGFA is the most functionally significant and best characterized. VEGFA signals via its main receptors, VEGFR1 (fms-related tyrosine kinase-1, Flt-1) and VEGFR2 (fetal liver kinase-1, Flk-1), and can also bind to semaphorin receptors, neuropilin (NRP)1 and NRP2. The impact of VEGFA on endothelial cell development and function is mainly achieved through binding to its tyrosine kinase receptor VEGFR2 with activation of downstream effectors, including PKC, PLC $\gamma$, MAPK and the PI3K/Akt/ PKB cascade [36]. In contrast to VEGFR2, VEGFR1 functions as a decoy receptor with stronger affinity for VEGFA but less tyrosine kinase activity, thus negatively regulating VEGF signaling.

Heterozygous mutants of Vegfa and homozygous mutants of Vegfr 2 are embryonic lethal at embryonic day (E) 11-12 and E8.5-9.5, respectively, due to defective blood-island formation and impaired vascular development $[37,38]$. However, $F l k-1^{-/-}$mouse embryonic stem cells are able to differentiate into hematopoietic and endothelial cells, although their subsequent migration and expansion requires a Flk-1-mediated signal, suggesting that VEGF signaling is dispensable for endothelial cell differentiation but may instead regulate EC survival $[39,40]$. Similarly, VEGF does not promote endothelial cell differentiation from human embryonic stem cells [7]. For VEGFR2 ${ }^{+}$mesodermal vas- cular progenitor cells, phosphorylation of VEGFR2 Y1175 and subsequent activation of the VEGFR2-PLC $\gamma 1$ axis and downstream Ras signaling is vital for endothelial lineage specification [41,42].

\subsection{Notch signaling}

Notch signaling is of vital importance in vascular development, and participates in processes such as vascular smooth muscle cell differentiation, arterial-venous cell fate specification, EC proliferation and angiogenic sprouting [43]. However, the role of Notch signaling in endothelial differentiation has not been defined. In growing vascular sprouts, VEGF induced the activation of Delta-like/Notch signaling, which suppresses tip cell fate in neighboring cells. One recent study expanded the prevailing model, showing that in endothelial progenitors (EPs), activation of the Notch pathway via VEGF-VEGFR2 signaling feeds back to inhibit Vegfr2 transcription and thereby limits EP maintenance and amplification [44]. Thus, VEGFA stimulation with Notch inhibition enhances EP formation and amplification, and blocks conversion of EPs to mature ECs. Moreover, Notch signaling regulates further EC specification by maintaining an arterial fate and inhibiting venous or lymphatic lineages [45].

\section{Transcriptional and epigenetic regulation of endothelial differentiation}

The specification of endothelial lineages requires a coordinated regulation of signaling molecules and transcriptional factors as well as epigenetic modifiers to direct endothelial-specific gene expression. The past decade has witnessed tremendous progress in dissecting the function of these transcription factors; however, the transcriptional regulatory network governing endothelial differentiation remains incompletely understood. Here we summarize several of the transcription factors and epigenetic mechanisms that are involved.

\subsection{ETS transcription factors}

E-twenty six (ETS) proteins are a group of DNA-binding transcription factors that are critical for endothelial development. ETS family members share a highly conserved ETS domain that binds to a core $5^{\prime}-\mathrm{GGA}(\mathrm{A} / \mathrm{T})-3^{\prime}$ sequence in target genes. To date, 26 mouse and 27 human ETS proteins have been identified [46], and 19 of them are expressed in human endothelial cells. All identified endothelial enhancers and promoters contain multiple ETS binding motifs [3], indicating that ETS factors may control most endothelial-related genes. Among the ETS factors regulating endothelial development, such as Ets-1, Erg, Fli-1, and Etv2, Etv2 (also known as Er71, ETS-related 71) is by far 
the best characterized.

During embryogenesis, Etv2 expression is initially widely spread within the primitive streak mesoderm, and then becomes more limited to major vessels at E8.5-9.5, and finally disappears beyond E10.5-11.5 [25,47]. This dynamic change of Etv2 expression reflects its role in early vascular development. In fact, Etv2 is a potent activator of several early endothelial genes, such as Flk1, Tall, Mef2c, Pecam and Tie2 [3]. Etv2 knockout mice are embryonic lethal due to a complete lack of blood vessels and hematopoietic cells $[25,48]$, and morpholino knockdown or mutation of etsrp, the Etv2 ortholog in zebrafish, results in complete deficiency in endothelial development [49,50]. Etv2 activation is critical for driving $\mathrm{Flk}-1^{+}$mesoderm differentiation and specifying Flk- $1^{+}$PDGFR $\alpha^{-}$hematopoietic and endothelial cell lineages, while suppressing the Flk- $1^{+}$PDGFR $\alpha^{+}$cardiac lineage [47,51,52], partly through inhibiting the WNT signaling pathway [53]. On the other hand, ensuring a tightly controlled Etv2 function is critical for proper development of the vascular system. Transgenic mice with constitutive Etv2 expression induced by Tie2-Cre display dilated yolk sac vessels accompanied with hemorrhaging and are eventually embryonic lethal [54]. In a recent study, transient Etv2 expression with constitutive Erg1 and Flil co-expression could reprogram amniotic cells into durable endothelial cells [55]. In summary, Etv2 plays a central early role in endothelial specification and acts near the top of the transcriptional network governing endothelial cell development.

ETS factor Fli also acts at the top of the transcriptional network governing hematopoietic and endothelial development. Knockdown of Fli in Xenopus substantially inhibits hematopoietic and endothelial differentiation, and activation of Fli transactivates early hemangioblast genes through $\mathrm{Scl}$, Etsrp and Cloche [56]. However, disruption of Fli in zebrafish fails to recapitulate the defects in Xenopus, and $\mathrm{Flil}^{-1-}$ mouse embryos do not display severe vascular defects but die of hemorrhage with loss of vascular integrity [57,58], indicating that $F l i$ is dispensable for EC development in zebrafish and mouse, but is required for vasculature formation after endothelial establishment. As a matter of fact, Fli acts downstream of Etv2 via a positive feedforward regulatory loop during vasculogenesis [59].

Redundancy between different ETS factors may explain the absence of vascular defects in knockout mouse studies. Mice with nonfunctional Erg, an ETS factor highly homologous to Fli, displayed no overt vascular phenotype with only dilated vessels in the brain [60]. Subsequent studies showed Erg regulated angiogenesis and endothelial survival by inducing adhesion molecule VE-cadherin and modulating HDAC6 function [61,62].

\subsection{Forkhead transcription factors}

The Forkhead (Fox) transcription factors play essential roles in vascular biology and endothelial function, and members that are of major importance in endothelial development include the FoxC, FoxF, FoxH and FoxO families [63]. Foxo1-deficient mice are embryonic lethal due to deregulated vascular development, including malformation of the aorta and internal carotid artery branches [64,65]. While mice deficient in Foxo3 did not show vascular defects, overexpression of Foxo1 and Foxo3 inhibited endothelial migration and tube formation, indicating a suppressive role of FOXO transcription factors in the regulation of vessel formation [66]. Foxf knockout mice showed defective mesodermal differentiation and disordered vascular patterning in the yolk sac [67]. Foxcl ${ }^{-/-}$and Foxc2 $2^{-/}$knockout mice are lethal by E9.5 with defective vascular remodeling and arteriovenous malformations [68].

FoxC proteins are important cofactors for ETS transcription factors, which together regulate endothelial gene expression [69]. Forkhead and ETS transcription factors can synergistically activate a composite cis-acting element called the FOX:ETS motif present in enhancers or promoters of a variety of endothelial genes such as VE-cadherin, Pecam1, Tie2, and Scl [69]. Coexpression of foxC2 and etv2 induces ectopic expression of vascular genes in Xenopus embryos, and simultaneous knockdown of the orthologous genes disrupts vascular development in zebrafish embryos [69]. In a recent study, foxcla/b was found to be a direct upstream regulator of etsrp in zebrafish [70]. Combined knockdown of foxcla/b led to a significant decrease in etsrp expression at early developmental stages, indicating that coordination of FoxC with ER71 is critical in mediating EC development [70].

\subsection{GATA transcription factors}

GATA transcription factors were initially thought to be required for hematopoietic development, because some early studies showed $\mathrm{Gatal}^{-/}$and $\mathrm{Gata2}^{-/-}$mice to be defective in erythropoiesis and to display anemia $[71,72]$. Subsequent studies found GATA also played an important role in hemangioblast formation and endothelial development [26]. GATA2 can induce the generation of Flk- $1^{+}$mesoderm, the Flk- ${ }^{+} \mathrm{Scl}^{+}$hemangioblasts and endothelial cells [26]. In fact, GATA binding sites are present in several endothelial genes, such as Flkl and VE-cadherin [73,74], and GATA regulates the endothelial gene, Endomucin, through epigenetic modulation [75].

\subsection{Epigenetic modifications}

Epigenetic control of EC differentiation involves DNA methylation of endothelial lineage promoters and posttranslational modification of histones. During differentiation, promoter regions of the genes involved in endothelial fate determination and homeostasis undergo intensive hypomethylation, allowing more efficient transcription [76-78]. 
Early studies showed inhibition of histone deacetylases (HDACs), enzymes that remove acetyl groups from lysine residues of histone proteins, blocked the endothelial differentiation of adult progenitor cells [79]. In contrast, laminar flow-induced activation of HDAC3 can promote EC differentiation [80]. Histone methylation with H3K27me marks an epigenetically silenced state, while $\mathrm{H} 3 \mathrm{~K} 4 \mathrm{me}$ permits gene activation. By pharmacologically inhibiting histone methyltransferase to reduce repressive H3K27me, endothelial progenitor cells (EPCs) increased expression of endothelial nitric oxide synthase (eNOS), and the reduction of $\mathrm{H} 3 \mathrm{~K} 27 \mathrm{me}$ was associated with an increase in the expression of the histone demethylase, Jmjd3 [81]. Ablation of Jmjd3 expectedly compromised mesoderm and subsequent endothelial differentiation, partly by silencing the mesodermal regulator Brachyury and reducing $\beta$-catenin recruitment [82]. On a practical level, targeting epigenetic repressive marks would yield more ECs differentiated from stem cells so as to enhance their function for bioengineering applications [83].

\section{3 microRNAs and EC differentiation}

microRNAs (miRNAs) are small, non-coding RNAs that play important regulatory roles in various aspects of development, homeostasis and disease by pairing to the mRNAs of protein-coding genes as negative and positive posttranscriptional regulators [84-86]. miRNAs are known to control the self-renewal and differentiation program of ES cells $[87,88]$. Numerous miRNAs have been shown to promote the differentiation of ESCs into various cell lineages, including cardiomyocytes [89], endothelial cells [90], smooth muscle cells [91] and skeletal muscle cells [92]. The switch from pluripotent to lineage-specific state by miRNAs involves repressing the self-renewal program by inhibiting core pluripotent factors and inducing the expression of lineage-specific gene products.

Global expression of miRNAs is essential for vascular development. Deletion of dicer in mouse led to embryonic death, due to defective blood vessel formation and maintenance $[93,94]$. In line with this observation, a mouse mutant with a hypomorphic dicerl resulted in female infertility caused by impaired growth of new capillary vessels in the corpus luteum [95]. Endothelial-selective ablation of dicer in mouse led to significant defects in postnatal angiogenesis in response to a variety of stimuli such as exogenous VEGF, ischemia, and wound healing [96]. Consistent with these observations, in vitro studies showed that knockdown of Dicer in human endothelial cells reduced capillary sprouting and tube formation by silencing several critical target miRNAs, such as lef-7f and mir-27b [97,98].

Roles of several miRNAs, including miR-126 [99,100], miR-221 [101], miR-132 [102], miR-218 [103,104], miR-23 27 24 clusters [105], miR-27a/b [106] and miR-92
[107], have been carefully examined in the regulation of vascular development, angiogenesis and endothelial functions through the fine-tuning of VEGF, Notch and Slit/Robo signaling pathways. Though many of the aforementioned miRNAs have been shown to regulate proper EC function, little is known about their role in EC differentiation. Some recent studies have identified several sets of miRNA that may participate during this process $[90,108,109]$, although many of them have not been directly tested with respect to being able to direct EC differentiation. Here, we summarize only those miRNAs with a definite role in promoting EC differentiation [110] (Figure 1).

\section{$3.1 \quad$ miR-21}

As one of the first mammalian miRNAs to be identified, miR-21 has been extensively studied and was found to be deregulated in many pathological conditions, including cancer and organ fibrosis [111]. Apart from its classic role as a tumor suppressor, recent studies have highlighted miR-21 as an important mediator during pathogenesis of cardiovascular disease, including angiogenesis [112], myocardial infarction [113,114] and ischemia/reperfusion [115], and in advanced peripheral arterial disease [116]. A recent genetic study on deletion of the neuronal repressor REST (RE1-silencing transcription factor) in embryonic stem cells also indicated a role of miR-21 in regulating stem cell self-renewal and differentiation [117]. REST is expressed at high levels in mouse embryonic stem cells, and is able to suppress a set of miRNAs that suppress stem cell selfrenewal and promote differentiation. Among them, miR-21 reduces the expression of pluripotent factors Oct4, Nanog, Sox 2 and c-Myc and specifically inhibits the self-renewal of

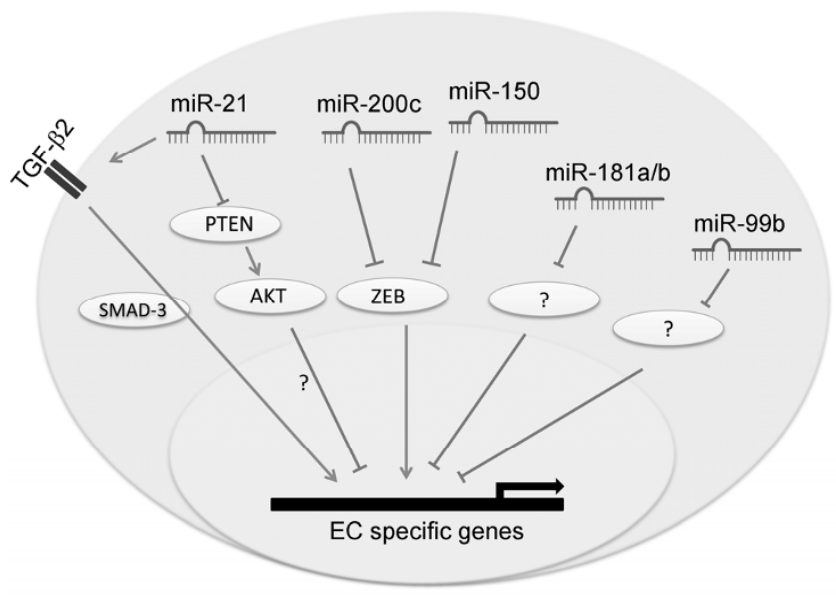

Figure 1 Roles of miRNAs in endothelial differentiation. miR-21 promotes endothelial differentiation through inhibition of the PTEN/Akt pathway. MiR-21 also increased TGF- $\beta 2$ production and subsequent EC gene activation in a SMAD3-dependent manner. MiR200c and miR-150 induce endothelial differentiation by transcriptionally de-repressing ZEB1 expression. miR-181a/b and miR-99b mediate EC lineage specification through as yet unknown mechanisms. 
mouse ES cells. Later studies showed that miR-21 is able to regulate differentiation of other cell lineages including monocyte-derived dendritic cells (MDDCs) [118], granulocytic cells [119] and adipogenic cells [120].

Our recent study on endothelial differentiation from induced pluripotent stem cells also indicated a role of miR-21 in regulating the TGF- $\beta$ signaling pathway [121]. Overexpression of miR-21 in pre-differentiated iPSCs induced capillary formation in vitro and in vivo, and increased levels of TGF- $\beta 2$ mRNA and secreted protein. TGF- $\beta 2$, in turn, promotes iPSCs differentiation towards the endothelial lineage through a SMAD3-dependent pathway. During endothelial cell differentiation, miR-21 targets the PTEN/Akt pathway and PTEN knockdown is required for miR-21 mediated upregulation of EC markers in differentiated iPSCs.

\section{2 miRNA-200 family}

The miR-200 family consists of five members: miR-200a, miR-200b, miR-200c, miR-141 and miR-429. These five miRNAs are located in two separate chromosomal clusters with the miR-200b-200a-429 cluster at chromosomal location $1 \mathrm{p} 36$ and miR-200c-141 cluster at 12p13. By targeting E-box-binding homeobox (ZEB) transcription factors, the miR-200 family negatively regulate epithelial-tomesenchymal transition (EMT) [122], which is crucial for embryogenesis and certain pathophysiological conditions, such as wound healing and carcinoma progression [123]. Expression of miR-200 is reduced in normal mammary stem cells, breast cancer stem cells (CSC) and embryonic carcinoma cell lines [124] and is up-regulated during ESC differentiation $[125,126]$. Overexpression of miR-200 suppresses expression of stem cell factors Bmi1 and Sox2 in CSCs and mouse ESCs, and induces differentiation $[124,126]$.

The ZEB-miR-200 interplay is also involved in endothelial differentiation of human ESCs [90]. ZEB1 transcriptionally repress EC-specific gene expression during EC differentiation. miR-200c de-represses this effect by inhibiting ZEB1 transcription, and thus promotes endothelial lineage differentiation. In a Matrigel-CD146 ${ }^{+}$EC-committing cell mixture implanted in mice, blocking ZEB1 signaling can rescue the inhibitory effect of miR-200c inhibition on in vivo vasculogenesis [90]. Interestingly, miR-200c promotes mesoderm specification while repressing neuroectodermal differentiation from ESCs [127], suggesting that miR-200c may play a cell-autonomous role in mediating EC differentiation from stem cells.

\section{3 miRNA-150}

miR-150 is classically involved in hematopoiesis and regulates cell differentiation in both lymphoid and myeloid lineages [128]. miR-150 is considered to be a tumor suppressive gatekeeper in leukemogenesis [129], and its aberrant expression is critical for pathogenesis in a variety of hematopoietic malignancies. The impact of miR-150 on endothelial cell differentiation seems similar to that of miR-200c, in that miR-150 also promotes endothelial lineage specification by transcriptionally repressing ZEB1 expression [90]. However, mice deficient in miR-150 are viable, fertile, and morphologically normal [130], indicating that the signaling networks in which miR-150 functions may not be essential for embryonic vasculogenesis, although such discrepancies could be attributed to the compensatory effects of other molecules in the knockout mice.

\section{4 miRNA-181}

The miR-181 family is composed of six members: miR181a1/2, miR-181b1/2, miR-181c, and miR-181d. They are expressed in a number of tissues, including muscle, eye, brain, lung and the hematopoietic compartment [131]. miR-181 family members play critical roles in controlling cardiovascular inflammation by regulating critical signaling pathways, such as the NF- $\mathrm{BB}$ pathway and molecules relevant to endothelial cell activation [132] and immune cell homoeostasis [133].

In a recent study employing miRNA microarray analysis during defined stages of EC differentiation from human ESCs, miR-181a and -181b were identified as increasing in a time-dependent manner to peak in mature hESC-ECs [109]. Overexpression of miR-181a and $-181 \mathrm{~b}$ enhanced levels of EC-specific genes, increased nitric oxide production, and improved hES-EC-induced therapeutic neovascularization in an in vivo model of peripheral ischemia. Knockdown of miR-181a and $-181 \mathrm{~b}$ significantly reduced vascular endothelial markers and nitric oxide production but had no effect on the cell population expressing endothelial marker proteins [109], suggesting that miR-181a and -181b may not be essential for EC lineage specification. This was confirmed in another knockout study of mice deficient in miR-181 that showed no obvious gross phenotypic abnormalities in terms of growth, development, or survival [134].

\section{5 miR-99 family}

The miRNA-99 family consists of miR-99a, -99b, and -100. They predominantly act as tumor suppressors by inducing cell cycle arrest [135] and inhibiting cell proliferation [136]. The miR-99 family also modulates injury responses, such as post-radiation DNA damage [137] and dermal wound healing [138]. miR-99b was co-identified with miR-181 in the study mentioned above as promoting EC differentiation from ESCs [109]. Like miR-181, augmentation of miR-99b induced EC-specific marker expression and nitric oxide generation, but its knockdown did not impact endothelial differentiation. This indicates that although capable of promoting EC differentiation from pluripotent ESCs, miR-99 is dispensable for EC differentiation. 


\subsection{Other miRNAs}

A series of new miRNAs regulating endothelial differentiation have been identified by Yoo et al. [139-141], but none of them have been functionally characterized. Among them, miR-5739 and miR-6087 modulate the expression of endoglin $[139,140]$, miR-6078 targets the E-cadherin (Cdh) gene [140], while miR-7641 suppresses expression of CXCL1 [141].

\section{Conclusion}

Recent years have witnessed progress in deciphering the molecular mechanism of endothelial differentiation; however, a comprehensive understanding of the exact differentiation program is still far from complete. Tissue engineering and stem cell therapy has important clinical implications for treating vascular diseases such as atherosclerosis and artery dissections; therefore, a better understanding of the EC differentiation program will greatly facilitate our ability to generate vessel cells from pluripotent stem cells. With the invention and maturation of iPS techniques, more specifically tailored cells that can be injected intravascularly will be made for producing bio-compatible vessels. As more details emerge of how endothelial cells are differentiated from stem cells, harnessing these differentiation mechanisms to enable the generation of endothelial cells from pluripotent stem cells will undoubtedly have future therapeutic implications of clinical value.

This work was supported by the National Natural Science Foundation of China (91339102, 81270001, 81270180) and the Zhejiang Provincial Natural Science Foundation (LR14H020001).

1 Fishman AP. Endothelium: a distributed organ of diverse capabilities. Ann N Y Acad Sci, 1982, 401: 1-8

2 Potente M, Gerhardt H, Carmeliet P. Basic and therapeutic aspects of angiogenesis. Cell, 2011, 146: 873-887

3 De Val S, Black BL. Transcriptional control of endothelial cell development. Dev Cell, 2009, 16: 180-195

4 Ferguson JE, 3rd, Kelley RW, Patterson C. Mechanisms of endothelial differentiation in embryonic vasculogenesis. Arterioscler Thromb Vasc Biol, 2005, 25: 2246-2254

5 Marcelo KL, Goldie LC, Hirschi KK. Regulation of endothelial cell differentiation and specification. Circ Res, 2013, 112: 1272-1287

6 Astorga J, Carlsson P. Hedgehog induction of murine vasculogenesis is mediated by Foxf1 and Bmp4. Development, 2007, 134: 3753-3761

7 Kelly MA, Hirschi KK. Signaling hierarchy regulating human endothelial cell development. Arterioscler Thromb Vasc Biol, 2009, 29: 718-724

8 Ingham PW, Nakano Y, Seger C. Mechanisms and functions of Hedgehog signalling across the metazoa. Nat Rev Genet, 2011, 12: 393-406

9 Byrd N, Grabel L. Hedgehog signaling in murine vasculogenesis and angiogenesis. Trends Cardiovasc Med, 2004, 14: 308-313

10 Dyer MA, Farrington SM, Mohn D, Munday JR, Baron MH. Indian hedgehog activates hematopoiesis and vasculogenesis and can respecify prospective neurectodermal cell fate in the mouse embryo. Development, 2001, 128: 1717-1730

11 Zhang XM, Ramalho-Santos M, McMahon AP. Smoothened mutants reveal redundant roles for Shh and Ihh signaling including regulation of L/R symmetry by the mouse node. Cell, 2001, 106: 781-792

12 Vokes SA, Yatskievych TA, Heimark RL, McMahon J, McMahon AP, Antin PB, Krieg PA. Hedgehog signaling is essential for endothelial tube formation during vasculogenesis. Development, 2004, 131: 4371-4380

13 Lawson ND, Vogel AM, Weinstein BM. sonic hedgehog and vascular endothelial growth factor act upstream of the Notch pathway during arterial endothelial differentiation. Dev Cell, 2002, 3: 127-136

14 Byrd N, Becker S, Maye P, Narasimhaiah R, St-Jacques B, Zhang X, McMahon J, McMahon A, Grabel L. Hedgehog is required for murine yolk sac angiogenesis. Development, 2002, 129: 361-372

15 Winnier G, Blessing M, Labosky PA, Hogan BL. Bone morphogenetic protein-4 is required for mesoderm formation and patterning in the mouse. Genes Dev, 1995, 9: 2105-2116

16 Chang H, Huylebroeck D, Verschueren K, Guo Q, Matzuk MM, Zwijsen A. Smad5 knockout mice die at mid-gestation due to multiple embryonic and extraembryonic defects. Development, 1999, 126: 1631-1642

17 Zhang P, Li J, Tan Z, Wang C, Liu T, Chen L, Yong J, Jiang W, Sun $\mathrm{X}$, Du L, Ding M, Deng H. Short-term BMP-4 treatment initiates mesoderm induction in human embryonic stem cells. Blood, 2008, 111: 1933-1941

18 Pearson S, Sroczynska P, Lacaud G, Kouskoff V. The stepwise specification of embryonic stem cells to hematopoietic fate is driven by sequential exposure to Bmp4, activin A, bFGF and VEGF. Development, 2008, 135: 1525-1535

19 Park C, Afrikanova I, Chung YS, Zhang WJ, Arentson E, Fong Gh G, Rosendahl A, Choi K. A hierarchical order of factors in the generation of FLK1- and SCL-expressing hematopoietic and endothelial progenitors from embryonic stem cells. Development, 2004, 131: 2749-2762

20 Park SW, Jun Koh Y, Jeon J, Cho YH, Jang MJ, Kang Y, Kim MJ, Choi C, Sook Cho Y, Chung HM, Koh GY, Han YM. Efficient differentiation of human pluripotent stem cells into functional CD34 ${ }^{+}$ progenitor cells by combined modulation of the MEK/ERK and BMP4 signaling pathways. Blood, 2010, 116: 5762-5772

21 Bai H, Gao Y, Arzigian M, Wojchowski DM, Wu WS, Wang ZZ. BMP4 regulates vascular progenitor development in human embryonic stem cells through a Smad-dependent pathway. J Cell Biochem, 2010, 109: 363-374

22 Goldman O, Feraud O, Boyer-Di Ponio J, Driancourt C, Clay D, Le Bousse-Kerdiles MC, Bennaceur-Griscelli A, Uzan G. A boost of BMP4 accelerates the commitment of human embryonic stem cells to the endothelial lineage. Stem Cells, 2009, 27: 1750-1759

23 Chiang PM, Wong PC. Differentiation of an embryonic stem cell to hemogenic endothelium by defined factors: essential role of bone morphogenetic protein 4. Development, 2011, 138: 2833-2843

24 Kim HY, Yang DH, Shin SW, Kim MY, Yoon JH, Kim S, Park HC, Kang DW, Min D, Hur MW, Choi KY. CXXC5 is a transcriptional activator of Flk-1 and mediates bone morphogenic protein-induced endothelial cell differentiation and vessel formation. FASEB J, 2014, 28: 615-626

25 Lee D, Park C, Lee H, Lugus JJ, Kim SH, Arentson E, Chung YS, Gomez G, Kyba M, Lin S, Janknecht R, Lim DS, Choi K. ER71 acts downstream of BMP, Notch, and Wnt signaling in blood and vessel progenitor specification. Cell Stem Cell, 2008, 2: 497-507

26 Lugus JJ, Chung YS, Mills JC, Kim SI, Grass J, Kyba M, Doherty JM, Bresnick EH, Choi K. GATA2 functions at multiple steps in hemangioblast development and differentiation. Development, 2007, 134: 393-405

27 Dejana E. The role of wnt signaling in physiological and pathological angiogenesis. Circ Res, 2010, 107: 943-952

28 Cattelino A, Liebner S, Gallini R, Zanetti A, Balconi G, Corsi A, Bianco P, Wolburg H, Moore R, Oreda B, Kemler R, Dejana E. The conditional inactivation of the beta-catenin gene in endothelial cells 
causes a defective vascular pattern and increased vascular fragility. $\mathrm{J}$ Cell Biol, 2003, 162: 1111-1122

29 Huelsken J, Vogel R, Brinkmann V, Erdmann B, Birchmeier C, Birchmeier W. Requirement for beta-catenin in anterior-posterior axis formation in mice. J Cell Biol, 2000, 148: 567-578

30 Kelly OG, Pinson KI, Skarnes WC. The Wnt co-receptors Lrp5 and Lrp6 are essential for gastrulation in mice. Development, 2004, 131: 2803-2815

31 Woll PS, Morris JK, Painschab MS, Marcus RK, Kohn AD, Biechele TL, Moon RT, Kaufman DS. Wnt signaling promotes hematoendothelial cell development from human embryonic stem cells. Blood, 2008, 111: 122-131

32 Lengerke C, Schmitt S, Bowman TV, Jang IH, Maouche-Chretien L, McKinney-Freeman S, Davidson AJ, Hammerschmidt M, Rentzsch F, Green JB, Zon LI, Daley GQ. BMP and Wnt specify hematopoietic fate by activation of the Cdx-Hox pathway. Cell Stem Cell, 2008, 2: $72-82$

33 Wang $\mathrm{H}$, Charles PC, Wu Y, Ren R, Pi X, Moser M, Barshishat-Kupper M, Rubin JS, Perou C, Bautch V, Patterson C. Gene expression profile signatures indicate a role for Wnt signaling in endothelial commitment from embryonic stem cells. Circ Res, 2006, 98: 1331-1339

34 Yang DH, Yoon JY, Lee SH, Bryja V, Andersson ER, Arenas E, Kwon YG, Choi KY. Wnt5a is required for endothelial differentiation of embryonic stem cells and vascularization via pathways involving both Wnt/beta-catenin and protein kinase Calpha. Circ Res, 2009, 104: 372-379

35 Olsson AK, Dimberg A, Kreuger J, Claesson-Welsh L. VEGF receptor signalling - in control of vascular function. Nat Rev Mol Cell Biol, 2006, 7: 359-371

36 Koch S, Tugues S, Li X, Gualandi L, Claesson-Welsh L. Signal transduction by vascular endothelial growth factor receptors. Biochem J, 2011, 437: 169-183

37 Carmeliet P, Ferreira V, Breier G, Pollefeyt S, Kieckens L, Gertsenstein M, Fahrig M, Vandenhoeck A, Harpal K, Eberhardt C, Declercq C, Pawling J, Moons L, Collen D, Risau W, Nagy A. Abnormal blood vessel development and lethality in embryos lacking a single VEGF allele. Nature, 1996, 380: 435-439

38 Shalaby F, Rossant J, Yamaguchi TP, Gertsenstein M, Wu XF, Breitman ML, Schuh AC. Failure of blood-island formation and vasculogenesis in Flk-1-deficient mice. Nature, 1995, 376: 62-66

39 Schuh AC, Faloon $\mathrm{P}$, Hu QL, Bhimani M, Choi K. In vitro hematopoietic and endothelial potential of flk-1(-/-) embryonic stem cells and embryos. Proc Natl Acad Sci USA, 1999, 96: 2159-2164

40 Nourse MB, Halpin DE, Scatena M, Mortisen DJ, Tulloch NL, Hauch KD, Torok-Storb B, Ratner BD, Pabon L, Murry CE. VEGF induces differentiation of functional endothelium from human embryonic stem cells: implications for tissue engineering. Arterioscler Thromb Vasc Biol, 2010, 30: 80-89

41 Kawasaki K, Watabe T, Sase H, Hirashima M, Koide H, Morishita Y, Yuki K, Sasaoka T, Suda T, Katsuki M, Miyazono K, Miyazawa K. Ras signaling directs endothelial specification of VEGFR2 ${ }^{+}$vascular progenitor cells. J Cell Biol, 2008, 181: 131-141

42 Sase H, Watabe T, Kawasaki K, Miyazono K, Miyazawa K VEGFR2-PLCgamma1 axis is essential for endothelial specification of VEGFR2 ${ }^{+}$vascular progenitor cells. J Cell Sci, 2009, 122: 3303-3311

43 Tung JJ, Tattersall IW, Kitajewski J. Tips, stalks, tubes: notch-mediated cell fate determination and mechanisms of tubulogenesis during angiogenesis. Cold Spring Harb Perspect Med, 2012, 2: a006601

44 Sahara M, Hansson EM, Wernet O, Lui KO, Spater D, Chien KR. Manipulation of a VEGF-Notch signaling circuit drives formation of functional vascular endothelial progenitors from human pluripotent stem cells. Cell Res, 2014, 24: 820-841

45 Murtomaki A, Uh MK, Choi YK, Kitajewski C, Borisenko V, Kitajewski J, Shawber CJ. Notch1 functions as a negative regulator of lymphatic endothelial cell differentiation in the venous endothelium. Development, 2013, 140: 2365-2376

46 Hollenhorst PC, McIntosh LP, Graves BJ. Genomic and biochemical insights into the specificity of ETS transcription factors. Annu Rev Biochem, 2011, 80: 437-471

47 Kataoka H, Hayashi M, Nakagawa R, Tanaka Y, Izumi N, Nishikawa S, Jakt ML, Tarui H. Etv2/ER71 induces vascular mesoderm from Flk1+PDGFRalpha+ primitive mesoderm. Blood, 2011, 118: 6975-6986

48 Ferdous A, Caprioli A, Iacovino M, Martin CM, Morris J, Richardson JA, Latif S, Hammer RE, Harvey RP, Olson EN, Kyba M, Garry DJ. Nkx2-5 transactivates the Ets-related protein 71 gene and specifies an endothelial/endocardial fate in the developing embryo. Proc Natl Acad Sci USA, 2009, 106: 814-819

49 Sumanas S, Lin S. Ets1-related protein is a key regulator of vasculogenesis in zebrafish. PLoS Biol, 2006, 4: e10

50 Pham VN, Lawson ND, Mugford JW, Dye L, Castranova D, Lo B, Weinstein BM. Combinatorial function of ETS transcription factors in the developing vasculature. Dev Biol, 2007, 303: 772-783

51 Rasmussen TL, Kweon J, Diekmann MA, Belema-Bedada F, Song Q, Bowlin K, Shi X, Ferdous A, Li T, Kyba M, Metzger JM, Koyano-Nakagawa N, Garry DJ. ER71 directs mesodermal fate decisions during embryogenesis. Development, 2011, 138: 48014812

52 Palencia-Desai S, Kohli V, Kang J, Chi NC, Black BL, Sumanas S. Vascular endothelial and endocardial progenitors differentiate as cardiomyocytes in the absence of Etsrp/Etv2 function. Development, 2011, 138: 4721-4732

53 Liu F, Kang I, Park C, Chang LW, Wang W, Lee D, Lim DS, Vittet D, Nerbonne JM, Choi K. ER71 specifies Flk-1+ hemangiogenic mesoderm by inhibiting cardiac mesoderm and Wnt signaling. Blood, 2012, 119: 3295-3305

54 Hayashi M, Pluchinotta M, Momiyama A, Tanaka Y, Nishikawa S, Kataoka H. Endothelialization and altered hematopoiesis by persistent Etv2 expression in mice. Exp Hematol, 2012, 40: 738-750 e711

55 Ginsberg M, James D, Ding BS, Nolan D, Geng F, Butler JM, Schachterle W, Pulijaal VR, Mathew S, Chasen ST, Xiang J, Rosenwaks Z, Shido K, Elemento O, Rabbany SY, Rafii S. Efficient direct reprogramming of mature amniotic cells into endothelial cells by ETS factors and TGFbeta suppression. Cell, 2012, 151: 559-575

56 Liu F, Walmsley M, Rodaway A, Patient R. Fli1 acts at the top of the transcriptional network driving blood and endothelial development. Curr Biol, 2008, 18: 1234-1240

57 Spyropoulos DD, Pharr PN, Lavenburg KR, Jackers P, Papas TS, Ogawa M, Watson DK. Hemorrhage, impaired hematopoiesis, and lethality in mouse embryos carrying a targeted disruption of the Fli1 transcription factor. Mol Cell Biol, 2000, 20: 5643-5652

58 Hart A, Melet F, Grossfeld P, Chien K, Jones C, Tunnacliffe A, Favier R, Bernstein A. Fli-1 is required for murine vascular and megakaryocytic development and is hemizygously deleted in patients with thrombocytopenia. Immunity, 2000, 13: 167-177

59 Abedin MJ, Nguyen A, Jiang N, Perry CE, Shelton JM, Watson DK, Ferdous A. Fli1 Acts Downstream of Etv2 to Govern Cell Survival and Vascular Homeostasis via Positive Autoregulation. Circ Res, 2014, 114: 1690-1699

60 Loughran SJ, Kruse EA, Hacking DF, de Graaf CA, Hyland CD, Willson TA, Henley KJ, Ellis S, Voss AK, Metcalf D, Hilton DJ, Alexander WS, Kile BT. The transcription factor Erg is essential for definitive hematopoiesis and the function of adult hematopoietic stem cells. Nat Immunol, 2008, 9: 810-819

61 Birdsey GM, Dryden NH, Amsellem V, Gebhardt F, Sahnan K, Haskard DO, Dejana E, Mason JC, Randi AM. Transcription factor Erg regulates angiogenesis and endothelial apoptosis through VE-cadherin. Blood, 2008, 111: 3498-3506

62 Birdsey GM, Dryden NH, Shah AV, Hannah R, Hall MD, Haskard DO, Parsons M, Mason JC, Zvelebil M, Gottgens B, Ridley AJ, Randi AM. The transcription factor Erg regulates expression of histone deacetylase 6 and multiple pathways involved in endothelial cell migration and angiogenesis. Blood, 2012, 119: 894-903 
63 Papanicolaou KN, Izumiya Y, Walsh K. Forkhead transcription factors and cardiovascular biology. Circ Res, 2008, 102: 16-31

64 Furuyama T, Kitayama K, Shimoda Y, Ogawa M, Sone K, Yoshida-Araki K, Hisatsune H, Nishikawa S, Nakayama K, Ikeda K, Motoyama N, Mori N. Abnormal angiogenesis in Foxo1 (Fkhr)-deficient mice. J Biol Chem, 2004, 279: 34741-34749

65 Hosaka T, Biggs WH, 3rd, Tieu D, Boyer AD, Varki NM, Cavenee WK, Arden KC. Disruption of forkhead transcription factor (FOXO) family members in mice reveals their functional diversification. Proc Natl Acad Sci USA, 2004, 101: 2975-2980

66 Potente M, Urbich C, Sasaki K, Hofmann WK, Heeschen C, Aicher A, Kollipara R, DePinho RA, Zeiher AM, Dimmeler S. Involvement of Foxo transcription factors in angiogenesis and postnatal neovascularization. J Clin Invest, 2005, 115: 2382-2392

67 Mahlapuu M, Ormestad M, Enerback S, Carlsson P. The forkhead transcription factor Foxf1 is required for differentiation of extra-embryonic and lateral plate mesoderm. Development, 2001, 128: $155-166$

68 Kume T, Jiang H, Topczewska JM, Hogan BL. The murine winged helix transcription factors, Foxc1 and Foxc2, are both required for cardiovascular development and somitogenesis. Genes Dev, 2001, 15: 2470-2482

69 De Val S, Chi NC, Meadows SM, Minovitsky S, Anderson JP, Harris IS, Ehlers ML, Agarwal P, Visel A, Xu SM, Pennacchio LA, Dubchak I, Krieg PA, Stainier DY, Black BL. Combinatorial regulation of endothelial gene expression by ets and forkhead transcription factors. Cell, 2008, 135: 1053-1064

70 Veldman MB, Lin S. Etsrp/Etv2 is directly regulated by Foxc1a/b in the zebrafish angioblast. Circ Res, 2012, 110: 220-229

71 Tsai FY, Keller G, Kuo FC, Weiss M, Chen J, Rosenblatt M, Alt FW, Orkin SH. An early haematopoietic defect in mice lacking the transcription factor GATA-2. Nature, 1994, 371: 221-226

72 Fujiwara Y, Browne CP, Cunniff K, Goff SC, Orkin SH. Arrested development of embryonic red cell precursors in mouse embryos lacking transcription factor GATA-1. Proc Natl Acad Sci USA, 1996, 93: $12355-12358$

73 Kobayashi-Osaki M, Ohneda O, Suzuki N, Minegishi N, Yokomizo T, Takahashi S, Lim KC, Engel JD, Yamamoto M. GATA motifs regulate early hematopoietic lineage-specific expression of the Gata2 gene. Mol Cell Biol, 2005, 25: 7005-7020

74 Khandekar M, Brandt W, Zhou Y, Dagenais S, Glover TW, Suzuki N, Shimizu R, Yamamoto M, Lim KC, Engel JD. A Gata2 intronic enhancer confers its pan-endothelia-specific regulation. Development, 2007, 134: 1703-1712

75 Kanki Y, Kohro T, Jiang S, Tsutsumi S, Mimura I, Suehiro J, Wada Y, Ohta Y, Ihara S, Iwanari H, Naito M, Hamakubo T, Aburatani H, Kodama T, Minami T. Epigenetically coordinated GATA2 binding is necessary for endothelium-specific endomucin expression. EMBO J, 2011, 30: 2582-2595

76 Lagarkova MA, Volchkov PY, Philonenko ES, Kiselev SL. Efficient differentiation of hESCs into endothelial cells in vitro is secured by epigenetic changes. Cell Cycle, 2008, 7: 2929-2935

77 Shirodkar AV, St Bernard R, Gavryushova A, Kop A, Knight BJ, Yan MS, Man HS, Sud M, Hebbel RP, Oettgen P, Aird WC, Marsden PA. A mechanistic role for DNA methylation in endothelial cell (EC)-enriched gene expression: relationship with DNA replication timing. Blood, 2013, 121: 3531-3540

78 Okada Y, Funahashi N, Tanaka T, Nishiyama Y, Yuan L, Shirakura K, Turjman AS, Kano Y, Naruse H, Suzuki A, Sakai M, Zhixia J, Kitajima K, Ishimoto K, Hino N, Kondoh M, Mukai Y, Nakagawa S, Garcia-Cardena G, Aird WC, Doi T. Endothelial cell-specific expression of roundabout 4 is regulated by differential DNA methylation of the proximal promoter. Arterioscler Thromb Vasc Biol, 2014, 34: 1531-1538

79 Rossig L, Urbich C, Bruhl T, Dernbach E, Heeschen C, Chavakis E, Sasaki K, Aicher D, Diehl F, Seeger F, Potente M, Aicher A, Zanetta L, Dejana E, Zeiher AM, Dimmeler S. Histone deacetylase activity is essential for the expression of HoxA9 and for endothelial commitment of progenitor cells. J Exp Med, 2005, 201: 1825-1835
80 Zeng L, Xiao Q, Margariti A, Zhang Z, Zampetaki A, Patel S, Capogrossi $\mathrm{MC}, \mathrm{Hu} \mathrm{Y}, \mathrm{Xu}$ Q. HDAC3 is crucial in shear- and VEGF-induced stem cell differentiation toward endothelial cells. J Cell Biol, 2006, 174: 1059-1069

81 Ohtani K, Vlachojannis GJ, Koyanagi M, Boeckel JN, Urbich C, Farcas R, Bonig H, Marquez VE, Zeiher AM, Dimmeler S. Epigenetic regulation of endothelial lineage committed genes in pro-angiogenic hematopoietic and endothelial progenitor cells. Circ Res, 2011, 109: 1219-1229

82 Ohtani K, Zhao C, Dobreva G, Manavski Y, Kluge B, Braun T, Rieger MA, Zeiher AM, Dimmeler S. Jmjd3 controls mesodermal and cardiovascular differentiation of embryonic stem cells. Circ Res, 2013, 113: 856-862

83 Thal MA, Krishnamurthy P, Mackie AR, Hoxha E, Lambers E, Verma S, Ramirez V, Qin G, Losordo DW, Kishore R. Enhanced angiogenic and cardiomyocyte differentiation capacity of epigenetically reprogrammed mouse and human endothelial progenitor cells augments their efficacy for ischemic myocardial repair. Circ Res, 2012, 111: 180-190

84 Bartel DP. MicroRNAs: target recognition and regulatory functions. Cell, 2009, 136: 215-233

85 Sayed D, Abdellatif M. MicroRNAs in development and disease. Physiol Rev, 2011, 91: 827-887

86 Vasudevan S, Tong Y, Steitz JA. Switching from repression to activation: microRNAs can up-regulate translation. Science, 2007, 318: 1931-1934

87 Martinez NJ, Gregory RI. MicroRNA gene regulatory pathways in the establishment and maintenance of ESC identity. Cell Stem Cell, 2010, 7: 31-35

88 Ivey KN, Srivastava D. MicroRNAs as regulators of differentiation and cell fate decisions. Cell Stem Cell, 2010, 7: 36-41

89 Zhao Y, Samal E, Srivastava D. Serum response factor regulates a muscle-specific microRNA that targets Hand2 during cardiogenesis. Nature, 2005, 436: 214-220

90 Luo Z, Wen G, Wang G, Pu X, Ye S, Xu Q, Wang W, Xiao Q. MicroRNA-200C and -150 play an important role in endothelial cell differentiation and vasculogenesis by targeting transcription repressor ZEB1. Stem Cells, 2013, 31: 1749-1762

$91 \mathrm{Xu} \mathrm{N}$, Papagiannakopoulos T, Pan G, Thomson JA, Kosik KS. MicroRNA-145 regulates OCT4, SOX2, and KLF4 and represses pluripotency in human embryonic stem cells. Cell, 2009, 137: 647-658

92 Chen JF, Mandel EM, Thomson JM, Wu Q, Callis TE, Hammond SM, Conlon FL, Wang DZ. The role of microRNA-1 and microRNA-133 in skeletal muscle proliferation and differentiation. Nat Genet, 2006, 38: 228-233

93 Bernstein E, Kim SY, Carmell MA, Murchison EP, Alcorn H, Li MZ, Mills AA, Elledge SJ, Anderson KV, Hannon GJ. Dicer is essential for mouse development. Nat Genet, 2003, 35: 215-217

94 Yang WJ, Yang DD, Na S, Sandusky GE, Zhang Q, Zhao G. Dicer is required for embryonic angiogenesis during mouse development. J Biol Chem, 2005, 280: 9330-9335

95 Otsuka M, Zheng M, Hayashi M, Lee JD, Yoshino O, Lin S, Han J. Impaired microRNA processing causes corpus luteum insufficiency and infertility in mice. J Clin Invest, 2008, 118: 1944-1954

96 Suarez Y, Fernandez-Hernando C, Yu J, Gerber SA, Harrison KD, Pober JS, Iruela-Arispe ML, Merkenschlager M, Sessa WC. Dicer-dependent endothelial microRNAs are necessary for postnatal angiogenesis. Proc Natl Acad Sci USA, 2008, 105: 14082-14087

97 Kuehbacher A, Urbich C, Zeiher AM, Dimmeler S. Role of Dicer and Drosha for endothelial microRNA expression and angiogenesis. Circ Res, 2007, 101: 59-68

98 Suarez Y, Fernandez-Hernando C, Pober JS, Sessa WC. Dicer dependent microRNAs regulate gene expression and functions in human endothelial cells. Circ Res, 2007, 100: 1164-1173

99 Fish JE, Santoro MM, Morton SU, Yu S, Yeh RF, Wythe JD, Ivey KN, Bruneau BG, Stainier DY, Srivastava D. miR-126 regulates angiogenic signaling and vascular integrity. Dev Cell, 2008, 15: 272-284 
100 Wang S, Aurora AB, Johnson BA, Qi X, McAnally J, Hill JA, Richardson JA, Bassel-Duby R, Olson EN. The endothelial-specific microRNA miR-126 governs vascular integrity and angiogenesis. Dev Cell, 2008, 15: 261-271

101 Nicoli S, Knyphausen CP, Zhu LJ, Lakshmanan A, Lawson ND. miR-221 is required for endothelial tip cell behaviors during vascular development. Dev Cell, 2012, 22: 418-429

102 Anand S, Majeti BK, Acevedo LM, Murphy EA, Mukthavaram R, Scheppke L, Huang M, Shields DJ, Lindquist JN, Lapinski PE, King PD, Weis SM, Cheresh DA. MicroRNA-132-mediated loss of p120RasGAP activates the endothelium to facilitate pathological angiogenesis. Nat Med, 2010, 16: 909-914

103 Small EM, Sutherland LB, Rajagopalan KN, Wang S, Olson EN. MicroRNA-218 regulates vascular patterning by modulation of Slit-Robo signaling. Circ Res, 2010, 107: 1336-1344

104 Fish JE, Wythe JD, Xiao T, Bruneau BG, Stainier DY, Srivastava D, Woo S. A Slit/miR-218/Robo regulatory loop is required during heart tube formation in zebrafish. Development, 2011, 138: 1409-1419

105 Zhou Q, Gallagher R, Ufret-Vincenty R, Li X, Olson EN, Wang S. Regulation of angiogenesis and choroidal neovascularization by members of microRNA-23 27 24 clusters. Proc Natl Acad Sci USA, 2011, 108: 8287-8292

106 Urbich C, Kaluza D, Fromel T, Knau A, Bennewitz K, Boon RA, Bonauer A, Doebele C, Boeckel JN, Hergenreider E, Zeiher AM, Kroll J, Fleming I, Dimmeler S. MicroRNA-27a/b controls endothelial cell repulsion and angiogenesis by targeting semaphorin 6A. Blood, 2012, 119: 1607-1616

107 Bonauer A, Carmona G, Iwasaki M, Mione M, Koyanagi M, Fischer A, Burchfield J, Fox H, Doebele C, Ohtani K, Chavakis E, Potente M, Tjwa M, Urbich C, Zeiher AM, Dimmeler S. MicroRNA-92a controls angiogenesis and functional recovery of ischemic tissues in mice. Science, 2009, 324: 1710-1713

108 Kane NM, Meloni M, Spencer HL, Craig MA, Strehl R, Milligan G, Houslay MD, Mountford JC, Emanueli C, Baker AH. Derivation of endothelial cells from human embryonic stem cells by directed differentiation: analysis of microRNA and angiogenesis in vitro and in vivo. Arterioscler Thromb Vasc Biol, 2010, 30: 1389-1397

109 Kane NM, Howard L, Descamps B, Meloni M, McClure J, Lu R, McCahill A, Breen C, Mackenzie RM, Delles C, Mountford JC, Milligan G, Emanueli C, Baker AH. Role of microRNAs 99b, 181a, and $181 \mathrm{~b}$ in the differentiation of human embryonic stem cells to vascular endothelial cells. Stem Cells, 2012, 30: 643-654

110 Zhou Y, Yang F, Wu Y, Yang M, Xiao Q. MicroRNAs in Endothelial Development and Differentiation. J Stem Cell Res Ther, 2014, 4: 2

111 Kumarswamy R, Volkmann I, Thum T. Regulation and function of miRNA-21 in health and disease. RNA Biol, 2011, 8: 706-713

112 Liu LZ, Li C, Chen Q, Jing Y, Carpenter R, Jiang Y, Kung HF, Lai L, Jiang BH. MiR-21 induced angiogenesis through AKT and ERK activation and HIF-1alpha expression. PLoS ONE, 2011, 6: e19139

113 Roy S, Khanna S, Hussain SR, Biswas S, Azad A, Rink C, Gnyawali S, Shilo S, Nuovo GJ, Sen CK. MicroRNA expression in response to murine myocardial infarction: miR-21 regulates fibroblast metalloprotease- 2 via phosphatase and tensin homologue. Cardiovasc Res, 2009, 82: 21-29

114 Dong S, Cheng Y, Yang J, Li J, Liu X, Wang X, Wang D, Krall TJ, Delphin ES, Zhang C. MicroRNA expression signature and the role of microRNA-21 in the early phase of acute myocardial infarction. J Biol Chem, 2009, 284: 29514-29525

115 Cheng Y, Zhu P, Yang J, Liu X, Dong S, Wang X, Chun B, Zhuang J, Zhang C. Ischaemic preconditioning-regulated miR-21 protects heart against ischaemia/reperfusion injury via anti-apoptosis through its target PDCD4. Cardiovasc Res, 2010, 87: 431-439

116 Wang M, Li W, Chang GQ, Ye CS, Ou JS, Li XX, Liu Y, Cheang TY, Huang XL, Wang SM. MicroRNA-21 regulates vascular smooth muscle cell function via targeting tropomyosin 1 in arteriosclerosis obliterans of lower extremities. Arterioscler Thromb Vasc Biol, 2011, 31: 2044-2053

117 Singh SK, Kagalwala MN, Parker-Thornburg J, Adams H, Majumder
S. REST maintains self-renewal and pluripotency of embryonic stem cells. Nature, 2008, 453: 223-227

118 Hashimi ST, Fulcher JA, Chang MH, Gov L, Wang S, Lee B. MicroRNA profiling identifies miR-34a and miR-21 and their target genes JAG1 and WNT1 in the coordinate regulation of dendritic cell differentiation. Blood, 2009, 114: 404-414

119 Velu CS, Baktula AM, Grimes HL. Gfi1 regulates miR-21 and miR-196b to control myelopoiesis. Blood, 2009, 113: 4720-4728

120 Kim YJ, Hwang SJ, Bae YC, Jung JS. MiR-21 regulates adipogenic differentiation through the modulation of TGF-beta signaling in mesenchymal stem cells derived from human adipose tissue. Stem Cells, 2009, 27: 3093-3102

121 Di Bernardini E, Campagnolo P, Margariti A, Zampetaki A, Karamariti E, Hu Y, Xu Q. Endothelial lineage differentiation from induced pluripotent stem cells is regulated by microRNA-21 and transforming growth factor beta2 (TGF-beta2) pathways. J Biol Chem, 2014, 289: 3383-3393

122 Park SM, Gaur AB, Lengyel E, Peter ME. The miR-200 family determines the epithelial phenotype of cancer cells by targeting the E-cadherin repressors ZEB1 and ZEB2. Genes Dev, 2008, 22: 894-907

123 Thiery JP, Acloque H, Huang RY, Nieto MA. Epithelialmesenchymal transitions in development and disease. Cell, 2009, 139: 871-890

124 Shimono Y, Zabala M, Cho RW, Lobo N, Dalerba P, Qian D, Diehn M, Liu H, Panula SP, Chiao E, Dirbas FM, Somlo G, Pera RA, Lao K, Clarke MF. Downregulation of miRNA-200c links breast cancer stem cells with normal stem cells. Cell, 2009, 138: 592-603

125 Bar M, Wyman SK, Fritz BR, Qi J, Garg KS, Parkin RK, Kroh EM, Bendoraite A, Mitchell PS, Nelson AM, Ruzzo WL, Ware C, Radich JP, Gentleman R, Ruohola-Baker H, Tewari M. MicroRNA discovery and profiling in human embryonic stem cells by deep sequencing of small RNA libraries. Stem Cells, 2008, 26: 2496-2505

126 Wellner U, Schubert J, Burk UC, Schmalhofer O, Zhu F, Sonntag A, Waldvogel B, Vannier C, Darling D, zur Hausen A, Brunton VG, Morton J, Sansom O, Schuler J, Stemmler MP, Herzberger C, Hopt U, Keck T, Brabletz S, Brabletz T. The EMT-activator ZEB1 promotes tumorigenicity by repressing stemness-inhibiting microRNAs. Nat Cell Biol, 2009, 11: 1487-1495

127 Du ZW, Ma LX, Phillips C, Zhang SC. miR-200 and miR-96 families repress neural induction from human embryonic stem cells. Development, 2013, 140: 2611-2618

128 He Y, Jiang X, Chen J. The role of miR-150 in normal and malignant hematopoiesis. Oncogene, 2013, doi: 10.1038/onc.2013.346

129 Jiang X, Huang H, Li Z, Li Y, Wang X, Gurbuxani S, Chen P, He C, You D, Zhang S, Wang J, Arnovitz S, Elkahloun A, Price C, Hong GM, Ren H, Kunjamma RB, Neilly MB, Matthews JM, Xu M, Larson RA, Le Beau MM, Slany RK, Liu PP, Lu J, Zhang J, Chen J. Blockade of miR-150 maturation by MLL-fusion/MYC/LIN-28 is required for MLL-associated leukemia. Cancer Cell, 2012, 22: 524-535

130 Xiao C, Calado DP, Galler G, Thai TH, Patterson HC, Wang J, Rajewsky N, Bender TP, Rajewsky K. MiR-150 controls B cell differentiation by targeting the transcription factor c-Myb. Cell, 2007, 131: $146-159$

131 Sun X, Sit A, Feinberg MW. Role of miR-181 family in regulating vascular inflammation and immunity. Trends Cardiovasc Med, 2014, 24: $105-112$

132 Sun X, Icli B, Wara AK, Belkin N, He S, Kobzik L, Hunninghake GM, Vera MP, Blackwell TS, Baron RM, Feinberg MW. MicroRNA$81 \mathrm{~b}$ regulates NF-kappaB-mediated vascular inflammation. J Clin Invest, 2012, 122: 1973-1990

133 Li QJ, Chau J, Ebert PJ, Sylvester G, Min H, Liu G, Braich R, Manoharan M, Soutschek J, Skare P, Klein LO, Davis MM, Chen CZ. miR-181a is an intrinsic modulator of $\mathrm{T}$ cell sensitivity and selection. Cell, 2007, 129: 147-161

134 Henao-Mejia J, Williams A, Goff LA, Staron M, Licona-Limon P, Kaech SM, Nakayama M, Rinn JL, Flavell RA. The microRNA miR-181 is a critical cellular metabolic rheostat essential for NKT 
cell ontogenesis and lymphocyte development and homeostasis. Immunity, 2013, 38: 984-997

135 Li D, Liu X, Lin L, Hou J, Li N, Wang C, Wang P, Zhang Q, Zhang P, Zhou W, Wang Z, Ding G, Zhuang SM, Zheng L, Tao W, Cao X. MicroRNA-99a inhibits hepatocellular carcinoma growth and correlates with prognosis of patients with hepatocellular carcinoma. J Biol Chem, 2011, 286: 36677-36685

136 Sun D, Lee YS, Malhotra A, Kim HK, Matecic M, Evans C, Jensen RV, Moskaluk CA, Dutta A. miR-99 family of microRNAs suppresses the expression of prostate-specific antigen and prostate cancer cell proliferation. Cancer Res, 2011, 71: 1313-1324

137 Mueller AC, Sun D, Dutta A. The miR-99 family regulates the DNA damage response through its target SNF2H. Oncogene, 2013, 32: 1164-1172

138 Jin Y, Tymen SD, Chen D, Fang ZJ, Zhao Y, Dragas D, Dai Y,
Marucha PT, Zhou X. MicroRNA-99 family targets AKT/mTOR signaling pathway in dermal wound healing. PLoS ONE, 2013, 8: e64434

139 Yoo JK, Kim J, Choi SJ, Kim CH, Lee DR, Chung HM, Kim JK. The hsa-miR-5739 modulates the endoglin network in endothelial cells derived from human embryonic stem cells. Biochem Biophys Res Commun, 2011, 415: 258-262

140 Yoo JK, Kim J, Choi SJ, Noh HM, Kwon YD, Yoo H, Yi HS, Chung HM, Kim JK. Discovery and characterization of novel microRNAs during endothelial differentiation of human embryonic stem cells. Stem Cells Dev, 2012, 21: 2049-2057

141 Yoo JK, Jung HY, Kim CH, Son WS, Kim JK. miR-7641 modulates the expression of CXCL1 during endothelial differentiation derived from human embryonic stem cells. Arch Pharm Res, 2013, 36: $353-358$

Open Access This article is distributed under the terms of the Creative Commons Attribution License which permits any use, distribution, and reproduction in any medium, provided the original author(s) and source are credited. 